\title{
Peningkatan Kapabilitas dan Performa UMKM melalui Monitoring dan Pendampingan
}

\author{
Improving the Capability and Performance of MSMEs through Monitoring and Assistance
}

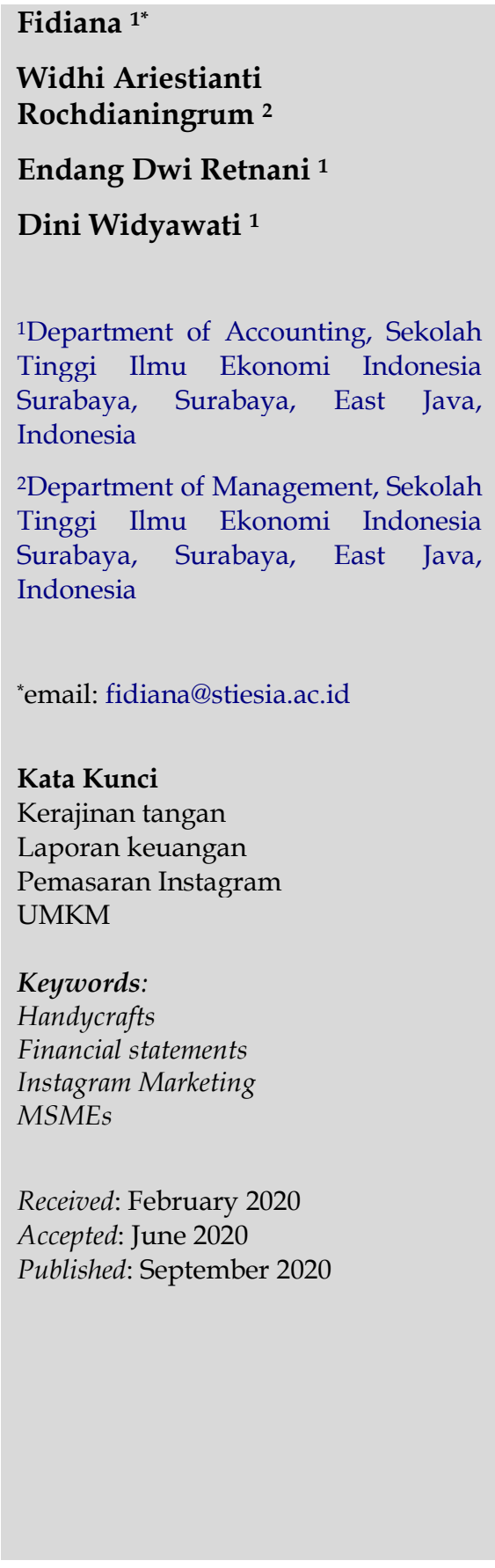

\begin{abstract}
Abstrak
Kegiatan pengabdian kepada masyarakat ini merupakan kegiatan berkesinambungan yang dilakukan dalam upaya mengembangkan kreatifitas ibu - ibu dalam menghasilkan produk yang inovatif dan menarik. Pada kegiatan ini dialukan pelatihan dan pendampingan penyusunan laporan keuangan dan pemasaran. Kegiatan ini dilakukan atas kerjasama Kecamatan Sukolilo dan STIESIA Surabaya. UMKM di Kecamatan Sukolilo mengalami beberapa kendala terkait penyusunan laporan keuangan, pemasaran yang memanfaakan media sosial, dan kendala teknis lainnya. Setelah kegiatan pendampingan ini, Ibu-Ibu pengelola UMKM memperleh beberapa manfaat antara lain telah memulai menyusun laporan keuangan. Kegiatan pelatihan pemasaran dilakukan dengan menggunakan media sosial instagram sebagai sarana produk yang dihasilkan. Pada kegiatan ini dilakukan pendampingan berupa pembuatan akun instagram, melakukan pemotretan produk yang akan di unggah pada instagram, melakukan pendampingan unggah foto produk pada instagram disertai dengan deskripsi produk sehingga dapat menarik konsumen. Kegiatan ini dilakukan untuk meningkatkan usaha yang dijalankan dari aspek manajemen. Sasaran yang ingin dicapai adalah ibu - ibu pelaku UMKM memiliki laporan keuangan yang dapat digunakan untuk mengajukan dana atau modal kepada bank guna pengembangan usahanya, memperluas jejaring pemasaran, dan meningkatkan penjualan.
\end{abstract}

\begin{abstract}
This community service activity is continuously carried out to develop the creativity of mothers in producing innovative and attractive products. This activity involves training and assistance in preparing financial and marketing reports. This activity was carried out in collaboration with the Sukolilo District and STIESIA Surabaya. MSMEs in Sukolilo District experienced several obstacles related to preparing financial reports, marketing that utilized social media, and other technical obstacles. After this mentoring activity, MSME managers gained several benefits, including having started compiling financial reports. Marketing training activities are carried out using Instagram social media as a means of producing products. In this activity, assistance was carried out to create an Instagram account, taking photos of products to be uploaded on Instagram, assisting in uploading product photos on Instagram accompanied by product descriptions so that they could attract consumers. This activity is carried out to improve the business carried out from the management aspect. The target to be achieved is that MSME players have financial reports that can be used to submit funds or capital to banks for business development, expand marketing networks, and increase sales.
\end{abstract}




\section{PENDAHULUAN}

Usaha mikro kecil menengah merupakan salah satu tonggak ekonomi di Indonesia. Usaha ini sebagian besar merupakan usaha yang berbasis pada kemampuan dan potensi yang ada dalam masyarakat (Lestari, 2010). Salah satu UMKM yang memiliki potensi untuk dikembangkan dan UMKM kerajinan tangan yang berada di kecamatanSukolilo Kota Surabaya. UMKMini merupakan UMKM yang terdiri dari sekolompok ibu ibu rumah tangga yang memproduksi beraneka ragam kerajinan tangan. Kerajinan tangan yang diproduksi antara lain kerudung, tas dari bungkus semen, bros, aneka rajutan, batik, kerajinan kain perca dan masih banyak lagi. Pembinaan dan pendampingan yang berkesinambungan perlu dilakukan pada UMKM ini agar UMKM ini dapat berkembang dengan baik dan dapat membatu ekonomi keluarga khususnya dan ekonomi masyarakat pada umumnya (Ribeiro-Soriano, 2017; Salazar-Elena \& Guimón, 2019; Thurik \& Wennekers, 2004; Xiang \& Worthington, 2017).

Berdasarkan hasil diskusi dengan ibu-ibu pelaku UMKM, permasalahan yang dihadapi selama ini adalah pertama, pengelolaan keuangan usaha yang bercampur dengan keuangan keluarga. Pada tahap ini belum ada spesifikasi atau upaya untuk memisahkan antara uang untuk kebutuhan rumah tangga dengan kebutuhan usaha. Selain itu, pengidentifikasian modal yang digunakan untuk memproduksi produk yang dihasilkan juga masih belum dilakukan. Pengelolaan administrasi keuangan usaha belum bisa dijalankan secara optimal sehingga pendapatan yang diterima dan pengeluaran usaha belum dapat diidentifikasi dengan jelas (Ernest, 2018). Padahal, pengelolaan keuangan usaha dengan teknik pembukuan sederhana sangat bermanfaat untuk memberikan informasi yang jelas mengenai posisi keuangan usaha setiap waktu; dapat memberikan informasi mengenai kondisi potensi pengembangan bisnis kedepannya dan beberapa informasi yang relevan (Collis \& Jarvis, 2002).

Permasalahan kedua yang dihadapi adalah Ibu-lbu UMKM Kecamatan Sukolilo adalah masalah pemasaran produk. Sejauh ini mereka memasarkan produknya pada lingkup terbatas seperti pada komunitas pengajian atau arisan. Sebagian besar pelaku UMKM di kecamatan Sukolilo merupakan ibu-ibu rumah tangga. Sebagian ada yang berusia 40 tahun keatas sehingga sangat terbatas untuk mampu memasarkan atau membuat saluran pemasaran menggunakan media dalam jaringan (daring) atau teknik pemasaran online. Sebagian lagi merupakan Ibu-lbu dengan usia kurang dari 40 tahun sehingga saluran e-commerce tidak sulit dilakukan. Untuk itu, tim pengabdi mencoba memberikan pendampingan bagi kedua kelompok ibu-ibu UMKM ini atas dasar usia; usia kurang dari 40 tahun didampingi dalam hal pembukuan sederhana dan saluran pemasaran online sementara bagi Ibu-lbu dengan usia lebih dari 40 tahun diberi pendampingan pembukuan dan teknik pemasaran berbasis Instagram. Semangat ibu-ibu untuk mencoba memasarkan produk yang dihasilkan secara on line cukup besar. Salama ini pemasaran yang dilakukan hanya sebatas megikuti pameran-pameran, dari mulut ke mulut serta memperkenalkan produk yang dihasilkan di Taman Harmoni, Kecamatan Keputih.

Pentingnya sistem pemasaran secara online pada saat ini pertama karena sudah tren di masyarakat juga sifat jangkauan pemasaran ini sangat luas (Grubor \& Jaksa, 2018). Kedua, pemasar lebih dapat mengenal konsumen barunya. Terakhir, dapat mempermudah hubungan antar pelanggan dengan merek yang ada (Chen \& Yang, 2014; Mathews et al., 2016). Kegiatan pemasaran online ini pada dasarnya memiliki tujuan akhir meningkatkan sampai level terakhir komunikasi kepada konsumen 
sehingga dapat dengan mudah mempengaruhi konsumen untuk membeli barang tersebut.

Kemampuan lain yang harus dimiliki adalah kemampuan dalam berkomunikasi dengan pelanggan maupun mitra bisnis. Seseorang dengan kemampuan komunikasi yang baik dapat menyampaikan informasi mengenai produk yang dihasilkan denganjelas sehingga dapat menyakinkan konsumen sehingga memiliki ketertarikan untuk melakukan langkah keputusan (Cherchye \& Verriest, 2016). Masalah lainnya adalah dukungan pendanaan untuk mengembangkan usaha. Dukungan pendanaan ini memang dibutuhkan bagi pelaku usaha kecil yang baru merintis usaha (Hartšenko \& Sauga, 2013).

\section{METODOLOGI}

Dalam kegiatan pengabdian ini digunakan dua metode yaitu metode pendampingan dan pelatihan. Pendampingan dilakukan dengan mengevaluasi perkembangan usaha setelah dilakukan pelatihan pembuatan kerajinan dan pemberian dana bergulir. Pendampingan dalam memonitoring perkembangan usaha dilakukan dengan cara berkomunikasi dan berdikusi mengenai apa yang telah dilaksanakan selama ini dan kendala yang dihadapi. Pada kegiatan ini, alat bantu yang digunakan adalah kuesioner yang dapat memberikan gamabaran umum perkembangan usaha. Pelatihan pada kegiatan ini dilakukan dengan memberikan pelatihan penyusunan pembukuan sederhana, cara membuat akun di instagram, menuliskan deskripsi yang menarik mengenai produk yang dihasilkan. Pada kegiatan ini juga dilakukan pelatihan cara berkomunikasi dengan pelanggan dan mitra bisnis. Pada kegiatan pelatihan, alat bantu yang digunakan adalah handphone untuk membuat akun intagram, nota atau bukti taransaksi untuk menyusun laporan keuangan.

\section{HASIL DAN PEMBAHASAN}

Kegiatan pelaksanaan pelatihan dan pendampingan bagi pelaku UMKM kecamatan Sukolilo merupakan kegiatan rutin yang berkelanjutan sejak bulan Maret 2019. Aktivitas pertama pada bulan Maret merupakan aktivitas pertama sehingga lebih banyak bersifat perkenalan dengan memberi pelatihan tentang pembuatan produk, pembukuan sederhana, kewajiban pajak bagi pelaku UMKM, serta pemasaran dan etika bisnis.

Sebulan setelah kegiatan pertama dilaksanakan, tim pengabdi memperoleh permintaan dari Kecamatan Sukolilo untuk memberikan pendampingan secara berkelanjutan atas kegiatan di bulan Maret 2019. Tim pengabdi merespon permintaan ini. Atas fasilitas dana bergulir dari STIESIA Surabaya, pada Bulan September 2019, lima kelompok UMKM Kecamatan Sukolilo memperoleh dana bergulir. Mekanisme pemberian bantuan dana bergulir atau modal bergulir berdasarkan kinerja ibu-ibu UMKM selama bulan Maret - September dan juga didasarkan pada masukan dari kecamatan. Fasilitas dana bergulir ini ternyata menjadi motivasi bagi Ibu-Ibu UMKM Kecamatan Sukolilo untuk mengembangkan usahanya dengan sungguh-sungguh (Hartšenko \& Sauga, 2013). Hal ini tampak dari permintaan pendampingan setelah penerimaan dana bergulir. Ibu-Ibu UMKM Kecamatan Sukolilo mengharapkan ada pendampingan untuk mengembangkan usaha.

Berikutnya, tim pengabdi STIESIA Surabaya mengembangkan strategi monitoring dan pendampingan dengan membentuk tim penanggungjawab yang terdiri dari beberapa mahasiswa untuk memonitor sekaligus mendampingi kebutuhan Ibu-Ibu UMKM Kecamatan Sukolilo seperti tampak pada Tabel I berikut: 
Tabel I. Daftar nama kelompok pendampingan penyusunan pembukuan

\begin{tabular}{lll}
\hline Nama UMKM & \multicolumn{1}{c}{ Pemilik } & \multicolumn{1}{c}{$\begin{array}{c}\text { Mahasiswa } \\
\text { Pendamping }\end{array}$} \\
\hline $\begin{array}{l}\text { Sakinah } \\
\text { Teratai }\end{array}$ & Selvi & Simon Peres \\
Yasinta Sulan & Rima & \\
& Filik & \\
\hline Dzakira Acc & Dian Amalia & Nekat Wahyu Bagus \\
Mawar & Ernawati & \\
ESM Collection & Ermine & Adelyana Mekar Sari \\
Arden & Ribut Hartini & \\
Collection & & \\
\hline Waru & Netty & Dewi Ika Sari \\
Eda Collection & Soeprodjo & \\
& Eri & \\
\hline Syandana & Dhanny & Larasati D Masyitah \\
Project & Yulinar & \\
Indah & Siamah & \\
\hline
\end{tabular}

Monitoring dan identifikasi masalah dan kebutuhan pelaku UMKM selain dilakukan secara door to door, juga dilakukan dengan membuka ruang komunikasi online melalui grup whatsapp yang bernama "Craf STIESIA". Grup ini beranggotakan ibu-ibu pelaku UMKM dan pihak STIESIA Surabaya. Pendampingan dari rumah ke rumah dilaksanakan dengan berdasarkan kesepakatan waktu antara mahasiswa pendamping dengan ibu-ibu pelaku UMKM kecamatan Sukolilo. Pelaksanaan kegiatan pendampingan ini tidak menganggu kegiatan produksi yang dilakukan oleh ibu-ibu serta tidak menganggu kegiatan akademik mahasiswa.

Pada bulan Januari 2020, tim pengabdi STIESIA Surabaya bekerja sama dengan Kecamatan Sukolilo mengadakan gathering bagi Ibu-lbu UMKM Kecamatan Sukolilo dengan tujuan untuk membahas perkembangan dan kemajuan usaha dan juga hambatan serta tantangan. Pada kegiatan ini, beberapa pelaku UMKM telah memaparkan kemajuan usahanya. UMKM perca kertas semen misalnya telah berhasil memasarkan usahanya bahkan hingga ke luar negeri. Beberapa pelaku UMKM yang lain juga memaparkan kemajuan usahanya hingga kewalahan menerima pesanan.

Kegiatan gathering ini juga mengembangkan saluran pemasaran dengan membuat akun instagram bagi beberapa usaha UMKM dan juga praktik menyusun laporan keuangan pada hari Selasa, tanggal 14 Januari tahun 2020, jam 08.30 hingga jam 12.00 WIB di Kantor Kecamatan Sukolilo yang dihadiri oleh 11 UMKM. Pada agenda ini, Ibu-lbu UMKM Kecamatan Sukolilo langsung mempraktikan menyusun laporan keuangan berdasarkan kwitansi dan bukti pembelian atau bukti penjualan yang telah ada.

Kedua, pelatihan pemasaran dilakukan dengan melalui diskusi mengenai cara pemasaran yang dilakukan selama ini. Sesi ini dilakukan untuk mengetahui cara pemasaran yang telah dilakukan selama ini serta bagaimana hasil yang didapatkan dari kegiatan pemasaran yang telah dilakukan. Berdasarkan hasil diskusi tersebut juga dapat dilakukan indentifikasi pelanggan produk yang dihasilkan oleh ibu-ibu UMKM. Pada pamasaran secara eletronik belum semua ibu-ibu memanfaat fasilitas ini. Sebagian ada yang menolak karena merasa terlalu sukar dimengerti, namun sebagian ingin belajar melakukan pemasaran secara online. Pada kegiatan ini, tahap awal yang dilakukan adalah membuatkan akun instagram UMKM dan menuliskan lokasi UMKM berada. Pada saat pendampingan penyusunan pembukuan sederhana diluar tanggal 14 Januari 2020, secara bertahap dilakukan pendampingan bagaimana menggunakan akun instagram untuk menjual produk yang dihasilkan. Dari tiga belas peserta pelatihan terdapat orang ibu-ibu yang bersedia untuk dibuatkan akun instagram yaitu ibu Ribut Hartini degan nama UMKM Arden Collection, ibu Ermine dengan nama UMKM ESM collection, ibu Dhanny Yulinar dengan nama UMKM Syandana Project, serta ibu Ernawati dengan nama UMKM Mawar.

Ketiga, identfikasi profil UMKM. Kegiatan ini dilakukan dengan melakukan wawancara kepada para ibu-ibu pelaku UMKM. Identifikasi UMKM dilakukan untuk melihat bagaimana perkembangan UMKM selama ini, 
potensi pengembangan kedepannya serta hambatan yang dihadapi dalam menjalankan usaha selama ini. Pada identifikasi profil UMKM ini, identfikasi meliputi jenis usaha, nama produk yang dihasilkan atau merek, rata-rata produk perbulan, omset yang dihasilkan perbulan, sumber bahan baku atau supplier, jumlah tenaga kerja yang digunakan, jenis peralatan produksi yang digunakan, pangsa pasar, cara pemasaran yang telah dilakukan atau dijalankan, serta pembukuan yang telah dijalankan.

Keempat, pelatihan cara berkomunikasi. Kemampuan komunikasi merupakan hal penting. Jika para pengusaha dapat menjelaskan kepada konsumen dengan baik dan menarik mengenai produk yang dihasilkan maka dapat membantu dalam memasarkan produk tersebut. Pada kegiatan ini ibu-ibu UMKM yang bersedia untuk mencoba menjelaskan mengenai produk yang dihasilkan, dipersilahkan maju kedepan untuk memperkenalkan produknya. Kemudian dosen pendamping mengajukan pertanyaan yang dapat menstimulasi ibu-ibu untuk dapat lebih menjelaskan produk yang dihasilkan. Penjelasan mengenai asal bahan baku, bagaimana produk tersebut dibuat atau diproduksi, bagaimana cara memasarkan produk yang dihasilkan, bagaimana tanggapan konsumen atas produk yang dihasilkan. Pada kegiatan ini ketika ibu-ibu memberikan pejelasan mahasiswa pendamping merekan kegiatan tersebut.

Kegiatan pendampingan yang merupakan keberlanjutan dari kegiatan pelatihan dilakukan sesuai kesepakatan waktu antara mahasiswa pendamping dengan ibu-ibu pelaku UMKM. Sebelum kegiatan pendampingan dilaksanakan, ibu-ibu pelaku usaha UMKM diminta untuk meyiapkan segala bukti transaksi kegiatan yang telah dilaksanakan. Adapun bukti yang disiapkan adalah bukti transaksi pengeluaran yang berkaitan dengan usaha yang dijalankan serta bukti penerimaan terkait dengan penjualan yang telah dilakukan. Pada kegiatan pendampingan ini, fokus utama kegiatan ini adalah membantu ibu-ibu dalam menyusun laporan keuangan atau pembukuan sederhana. Adapun jenis laporan yang disusun adalah laporan kas, laporan utang, laporan piutang, laporan inventaris, neraca serta laba rugi. Setiap mahasiswa pendamping akan mendamping ibu-ibu pada tahan awal penyusunan. Setelah kegiatan ini berjalan mahasiswa pendamping dan dosen pendamping melakukan monitoring perkembangan pelaksanaan kegiatan ini. Fokus kedua dari kegiatan pendampingan ini adalah memberikan pendampingan menggunakan media sosial instagram sebagai salah satu sarana dalam mempromosikan produk yang dihasilkan. Kegiatan ini dilakukan dengan melalui pendampingan mengunggah foto produk dalam instagram menulis caption yang menarik sehingga pengguna instagram yang melihatnya menjadi tertarik dengan produk tersebut. Bukan hanya membantu dalam mengupload foto, kegiatan pendampingan ini juga dilakukan dengan membantu ibu-ibu dalam mengambil foto guna keperluan di instagram. Kegiatan ini dilakukan setelah tanggal 14 Januari 2020 sampai dengan bulan pertengahan februari sebelum kegiatan perkuliahan untuk semester genap berlangsung.

Kegiatan monitoring dilaksanakan pada minggu kedua sampai minggu ketiga bulan februari. Kegiatan ini dilakukan dengan melihat bagaimana perkembangan kegiatan pelatihan dan pendampingan yang telah dilaksanakan. Berdasarkan hasil kegiatan monitoring didapatkan bahwa terdapat beberapa ibu-ibu UMKM yang memulai menjalankan kegiatan penyusunan laporan keuangan, diataranya ibu Dhanny, Ibu Eri, Ibu Ermin dan Ibu Netty. Pada awal penyusunan laporan keuangan ini, menurut ibu-ibu cukup sulit dan membingungkan, namun setelah mendapatkan 
pendampingan dan berkomunikasi secara intensif ibuibu mulai memahami bagaimana alur bekerjanya penyusunan laporan keuangan. Beberapa ibu-ibu juga telah memulai menggunakan akun instagramnya dalam memasarkan produk yang dihasilkannya. Tampilan akun Instagram disajikan pada Gambar 1.

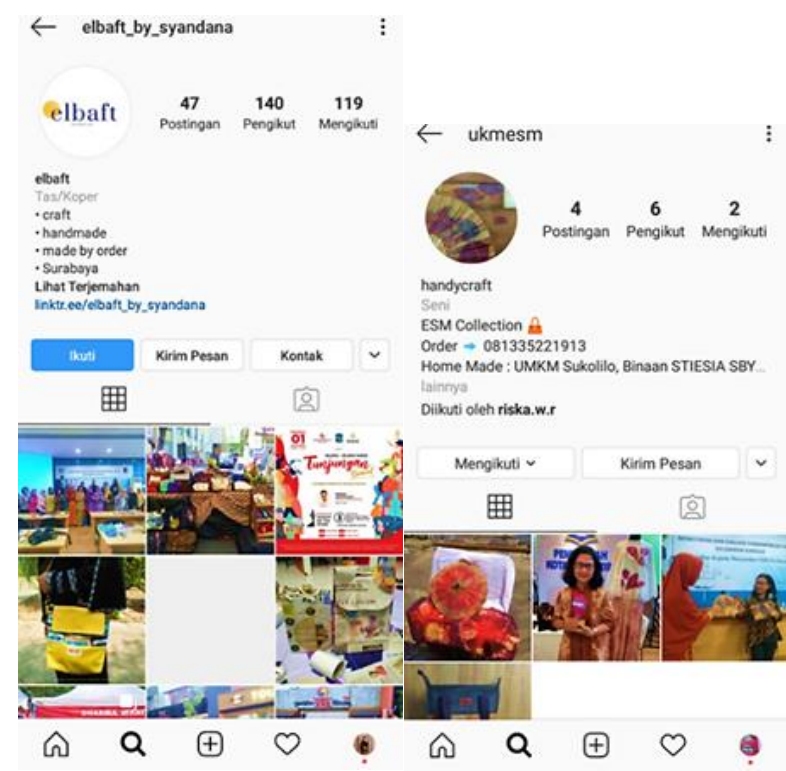

Gambar 1. akun Instagram pelaku UMKM

Dua gambar diatas merupakan akun intagram ibu-ibu UMKM handy craft kecamatan Sukolilo. Tidak semua ibu-ibu bersedia menggunakan instagram sebagai media promosi produk yang dihasilkan. Ibu-ibu yang bersedia terus kita dorong untuk meningkatkan kemampuannya dalam menyakinkan pelanggan. Bukan hanya melalui instagram dalam rangka memperkenalkan UMKM binaan STIESIA Surabaya, maka kegiatan ini juga didokumentasikan dalam bentuk video yang diunggah dalam akun youtube STIESIA Surabaya.

\section{KESIMPULAN}

Berdasarkan hasil kegiatan yang telah dilakukan dapat disimpulkan pertama, Ibu-ibu pelaku UMKM memiliki keinginan untuk dapat menyusun pembukuan sederhana dan pencatatan. Hal ini dapat dilihat dari banyaknya permintaan ibu-ibu untuk didampingi menyusun pembukuan sederhana dan pencatatan di luar waktu pelatihan dan pendampingan. Kedua, meskipun pada awalnya mengalami sedikit kesulitan, ibu-Ibu pelaku UMKM yang berusia 40 tahun keatas tetap antusias untuk belajar memasarkan produk yang dihasilkan dengan menggunakan Instagram. Ketiga, kegiatan bantuan modal bergulir yang diberikan dimanfaatkan oleh ibu-ibu untuk mengembangkan usaha yang dijalankan. Contohnya pada ibu Siamah yang pada awalnya memiliki usaha hantaran lamaran sekarang usahanya berkembang dengan memproduksi minuman tradisional dan bumbu pecel. Keempat, dalam hal cara berkomunikasi dengan pelanggan tingkat percaya diri ibu-ibu perlu untuk ditingkatkan sehingga dapat lebih menyakinkan konsumen sebelumnya.

\section{UCAPAN TERIMA KASIH}

Terselengaranya kegiatan ini dengan lancar merupakan dukungan dari berbagai pihak. Ucapan terimakasih diberikan kepada Yayasan Perpendiknas yang telah membiayai kegiatan ini, Ketua STIESIA Surabaya atas segala dukungan, Ibu Amalia Camat Sukolilo, Ibu Ratih Kasi Kesra Kecamatan Sukolilo, Ketua LP2M STIESIA Surabaya, mahasiswa STIESIA, serta pihak lainnya yang tidak dapat disebut satu persatu dalam kegiatan ini.

\section{REFERENSI}

Chen, L.S., Yang, T.Y.K. 2014. Increasing Customer Loyalty in Internet Marketing. In: Pan, J.S., Snasel, V., Corchado, E., Abraham, A., Wang, S.L. (Eds). Intelligent Data analysis and its Applications, Volume II. Advances in Intelligent Systems and Computing. 298. Cham: Springer Nature. https://doi.org/10.1007/978-3-31907773-4_10

Cherchye, L., Verriest, A. 2016. The impact of homecountry institutions and competition on firm profitability. International Business Review. 25(4):831-846.

https://doi.org/10.1016/j.ibusrev.2015.10.005 
Collis, J., Jarvis, R. 2002. Financial information and the management of small private companies. Journal of Small Business and Enterprise Development. $\quad$ 9(2):100-110. https://doi.org/10.1108/14626000210427357

Ernest, N. 2018. The Role of Bookkeeping on the Survival of Very Small Businesses in the Kumba Municipality. International Journal of Advanced Engineering, Management and Science. 4(10):713723.

https://dx.doi.org/10.22161/ijaems.4.10.1

Grubor, A., Jaksa, O. 2018. Internet Marketing as a Business Necessity. Interdisciplinary Description of Complex Systems. 16(2):265-274. http://dx.doi.org/10.7906/indecs.16.2.6

Hartšenko, J., Sauga, A. 2013. The role of financial support in SME and economic development in Estonia. Business and Economic Horizons. 9(2):10-22.

http://dx.doi.org/10.15208/beh.2013.6

Lestari, E.P. 2010. Penguatan Ekonomi Industri Kecil Dan Menengah Melalui Platform Klaster Industri. Jurnal Organisasi dan Manajemen. 6(2):146-157.

Mathews, S., Bianchi, C., Perks, K.J., Healy, M., Wickramasekera, R. 2016. Internet marketing capabilities and international market growth. International Business Review. 25(4):820-830. https://doi.org/10.1016/j.ibusrev.2015.10.007

Ribeiro-Soriano, D. 2017. Small business and entrepreneurship: their role in economic and social development. Entrepreneurship and Regional Development. 29(1-2):1-3. https://doi.org/10.1080/08985626.2016.12554 38

Salazar-Elena, J.C., Guimón, J. 2019. Management practices and small firms' productivity in emerging countries. Competitiveness Review. 29(4):356-374. https://doi.org/10.1108/CR01-2019-0004

Thurik, R., Wennekers, S. 2004. Entrepreneurship, small business and economic growth. Journal of Small Business and Enterprise Development. 11(1):140149. https://doi.org/10.1108/14626000410519173

Xiang, D., Worthington, A.C. 2017. The impact of government financial assistance on the performance and financing of Australian
SMEs. Accounting Research Journal. 30(4):447464. https://doi.org/10.1108/ARJ-04-20140034 